\title{
PRMT1 Inhibitor
}

National Cancer Institute

\section{Source}

National Cancer Institute. PRMT1 Inhibitor. NCI Thesaurus. Code C158131.

Any agent that inhibits protein arg inine N-methyltransferase 1 (PRMT 1; histone-arg inine $\mathrm{N}$-methyltransferase PRMT1; interferon receptor 1-bound protein 4). 